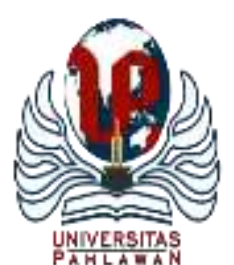

\title{
JURNALBASICEDU
}

Volume 6 Nomor 1 Tahun 2022 Halaman 1398 - 1407

Research \& Learning in Elementary Education

https://jbasic.org/index.php/basicedu

\section{Potensi Pemberdayaan Keterampilan Berpikir Kritis Mahasiswa Calon Guru Sekolah Dasar Melalui Model Discovery Learning}

\author{
Anggit Grahito Wicaksono \\ Program Studi Pendidikan Guru Sekolah Dasar, Universitas Slamet Riyadi, Indonesia \\ E-mail: garahito@gmail.com
}

\begin{abstract}
Abstrak
Keterampilan berpikir kritis merupakan salah satu keterampilan penting di abad 21. Masalah keterampilan berpikir kritis mahasiswa harus diminimalkan dengan menggunakan model pembelajaran yang akurat. Model Discovery Learning akan membantu mahasiswa memperkuat berpikir kritis. Penelitian ini bertujuan untuk menganalisis potensi model Discovery Learning dalam memberdayakan keterampilan berpikir kritis mahasiswa. Penelitian ini merupakan penelitian deskriptif dengan data dikumpulkan melalui tinjauan kepustakaan. Hasil dari penelitian ini menunjukkan bahwa model pembelajaran Discovery Learning memiliki potensi besar dalam membangun keterampilan berpikir kritis mahasiswa. Tahapan-tahapan dalam model Discovery Learning saling bersinergi dalam mewujudkan pembelajaran yang mandiri dan melatih kemampuan berpikir mahasiswa. Model pembelajaran Discovery Learning memberikan pengalaman pada mahasiswa untuk menemukan pengetahuan sendiri dan menggunakan pendekatan ilmiah. Sintaks model pembelajaran Discovery Learning memiliki keterkaitan serta berpotensi dapat memberdayakan keterampilan berpikir kritis mahasiswa. Sintaks yang ada pada model pembelajaran Discovery Learning yang meliputi stimulation, problem statement, data collection, data processing, verification, dan generalization mampu melatihkan dan memberdayakan keterampilan berpikir kritis pada mahasiswa menjadi lebih terarah.
\end{abstract}

Kata Kunci: Model Discovery Learning, Keterampilan Berpikir Kritis, Mahasiswa

\begin{abstract}
Critical thinking skills are one of the skills needed in the 21 st century. The problem of students' critical thinking skills must be minimized by using an accurate learning model. The Discovery Learning model will help students strengthen their critical thinking skills. This study aims to analyze the Discovery Learning model in empowering students' critical thinking skills. This research is descriptive research with data collected through literature study. The results of this study indicate that the Discovery Learning model has great potential in building students' critical thinking skills. The stages in the Discovery Learning model work together to create independent learning and train students' thinking skills. Discovery Learning experiential learning model for students to find their knowledge and provide a scientific approach. The Discovery Learning Syntax model is related and has the opportunity to empower students' critical thinking skills. The syntax in the Discovery Learning model which includes stimulation, problem statements, data collection, data processing, verification, and generalization can train and empower students' critical thinking skills to be more focused.
\end{abstract}

Keywords: Discovery Learning Model, Critical Thinking Skills, Student

Copyright (c) 2022 Anggit Grahito Wicaksono

$\triangle$ Corresponding author :

Email : garahito@gmail.com

DOI : https://doi.org/10.31004/basicedu.v6i1.2229

ISSN 2580-3735 (Media Cetak)

ISSN 2580-1147 (Media Online)

Jurnal Basicedu Vol 6 No 1 Tahun 2022

p-ISSN 2580-3735 e-ISSN 2580-1147 


\section{PENDAHULUAN}

Pendidikan hendaknya mengutamakan pengembangan seluruh potensi individu untuk mempersiapkan sumber daya manusia yang berkualitas. Sumber daya manusia yang dapat menjawab tantangan perkembangan zaman yang semakin cepat dan dinamis harus memiliki kecerdasan yang tinggi. Keterampilan intelektual yang tinggi ditandai dengan keterampilan berpikir kritis dan kreatif serta kompetitif yang mampu mengkomunikasikan ide dan memecahkan segala permasalahan. Keterampilan intelektual individu mampu berkembang melalui pendidikan. Di era perkembang teknologi, modal keterampilan intelektual, terutama keterampilan berpikir tingkat tinggi, merupakan tuntutan sumber daya manusia di abad ke-21 (Galbreath, 1999). Keterampilan berpikir kritis berperan dalam kemampuan mahasiswa untuk secara efektif memecahkan masalah sosial dan ilmiah serta praktis di masa depan (Arifani et al., 2017; Ebiendele Ebosele Peter, 2012; Snyder \& Snyder, 2008). Keterampilan berpikir kritis merupakan proses intelektual untuk menyusun konsep, menguraikan, mengimplementasikan, dan memberikan penilaian terhadap semua informasi yang diperoleh dari proses pengamatan dimana hasilnya digunakan sebagai landasan pengukuran (Walker \& Finney, 2006).

Kualitas pendidikan di Indonesia tetap menjadi perhatian utama, berdasarkan hasil pengukuran PISA tahun 2016, Indonesia menempati peringkat ke-62 dari 72 negara yang per tahun 2018 secara bertahap mengalami penurunan. Hal ini diukur melalui keterampilan sains, membaca dan matematika serta terkait dengan keterampilan intelektual (Munawwarah et al., 2020). Keterampilan intelektual meliputi keterampilan berpikir logis, sistematis, kritis, cermat dan kreatif. Hasil pengukuran keterampilan intelektual tersebut menunjukkan rendahnya kualitas pendidikan di Indonesia yang salah satunya adalah keterampilan berpikir kritis. Hasil penelitian yang senada menujukkan bahwa mahasiswa PGSD STKIP Muara bungo memiliki Keterampilanberpikir kritis dengan tingkat rata-rata (sedang) sebesar 48,8\%, kemudian dengan kriteria rendah 26,7\%. Kriteria sangat tinggi sebesar 4,6\%, tinggi, 11,6\% dan rendah hanya 8,1 \% (Wiyoko, 2019). Penelitian lain yang sejenis menunjukkan bahwa Keterampilanberpikir kritis rata-rata mahasiswa PGSD FKIP Universitas Tadulako kelas A sebesar 45\% kemudian untuk kelas B sebesar 39,7\% dan kelas C sebesar 40,7\%. Profil keterampilan berpikir kritis mahasiswa pada kelas A berdasarkan kriteria tinggi sebesar 22,7\%, sedang $70,4 \%$ dan rendah 6,8\%. Keterampilan berpikir kritis mahasiswa di kelas B dengan kriteria tinggi 13,6\%, sedang $72,7 \%$, rendah 13,6\%, sedangkan di kelas C mahasiswa dengan kriteria tinggi $20,4 \%$, sedang $72,7 \%$ dan rendah sebesar 6,8\% (Firmansyah \& Rizal, 2019).

Masalah keterampilan berpikir kritis mahasiswa harus mampu diselesaikan dengan menggunakan model pembelajaran yang tepat. Berpikir kritis mahasiswa dapat meningkat melalui penggunaan model Discovery Learning. Keenam sintaks model Discovery Learning dapat memberdayakan keterampilan berpikir kritis mahasiswa (Bruner, 2009). Hal ini sesuai dengan pendapat bahwa seorang individu dengan keterampilan berpikir kritis dapat berperilaku secara konsisten dalam menghadapi sebagian dari keseluruhan masalah (Ennis, 1996). Sistem berpikir yang ada akan diperkuat dengan menerapkan enam sintaks pada model Discovery Learning.

Kekuatan model pembelajaran penemuan (Discovery Learning) adalah pengetahuan yang diperoleh melalui model ini sangat personal dan powerful karena meningkatkan kemampuan memahami, mengingat dan mentransfer (Kemendikbud, 2013). Salah satu ukuran keberhasilan model pembelajaran penemuan merupakan internalisasi peristiwa yang tersimpan pada lingkungan yang adaptif (Ozdem-Yilmaz \& Bilican, 2020; Takaya, 2008). Model pembelajaran penemuan berpengaruh besar terhadap peningkatan keterampilan berpikir kritis mahasiswa. Pembelajaran dengan menggunakan model pembelajaran penemuan menjadikan keterampilan berpikir kritis lebih baik dibandingkan pembelajaran konvensional. Memang kemampuan berpikir kritis mahasiswa menjadi lebih berkembang, mahasiswa dapat mencari pengetahuan sendiri, mahasiswa menjadi lebih aktif dalam pembelajaran yang berpusat pada mahasiswa, dan bukan pada dosen (Batubara, 2020; Susanti et al., 2020). Tujuan utama penggunaan model Discovery Learning adalah untuk 
melibatkan mahasiswa dalam berpikir sesuai dengan kebutuhannya, membantu mahasiswa menemukan cara untuk memperoleh pengetahuan, dan mendukung keterampilan berpikir tingkat tinggi, salah satunya adalah berpikir kritis (Efendi, 2019; Sakti et al., 2020). Berdasarkan alasan tersebut, kajian pustaka ini dilakukan untuk menganalisis potensi model pembelajaran penemuan dalam meningkatkan keterampilan berpikir kritis.

\section{METODE PENELITIAN}

Penelitian ini merupakan penelitian deskriptif tentang potensi Discovery Learning untuk meningkatkan keterampilan berpikir kritis. Data untuk penelitian ini dikumpulkan melalui studi literatur. Metode library research merupakan metode untuk mengumpulkan data yang berkaitan dengan topik yang dibahas dalam suatu penelitian (Danandjaja, 2014; Sari \& Asmendri, 2018). Studi literatur dapat diambil dari berbagai sumber, jurnal, buku, dan dokumen. Penelitian ini difokuskan pada potensi Discovery Learning untuk meningkatkan keterampilan berpikir kritis.

\section{HASIL DAN PEMBAHASAN}

\section{Keterampilan Berpikir Kritis}

Berpikir merupakan aktivitas mental dalam pemecahan permasalahan (Anugraheni, 2019). Keterampilan berpikir ada dua jenis, yaitu berpikir tingkat tinggi dan berpikir tingkat rendah. Keterampilan berpikir tingkat tinggi meliputi berpikir kritis, metakognisi, logika, kreativitas, dan refleksi (Sucipto, 2017). Berpikir kritis adalah proses menentukan kebenaran atau nilai dari sesuatu yang ditandai dengan keterampilan menalar dan memilih, mengamati situasi dengan cermat, dan mengubah pendapat berdasarkan bukti (Wicaksono, 2020). Berpikir kritis memiliki definisi singkat, yaitu berpikir logis dan rasional, berfokus pada pengambilan keputusan tentang apa yang harus diyakini dan dilakukan (Ennis, 2015). Berpikir kritis dapat membawa hasil sekaligus manfaat, karena dengan berpikir kritis mahasiswa dapat membuat penilaian terhadap sumber-sumber yang telah ditemukan (Lai, 2011; Mulyono, 2018). Keterampilan berpikir kritis adalah proses yang terampil dan aktif secara intelektual dalam mengkonseptualisasikan, mengimplementasikan, menguraikan, atau mengevaluasi kumpulan informasi melalui pengamatan, menyimpulkan atau berkomunikasi, sebagai landasan untuk melakukan tindakan (Facione \& Facione, 2013).

Ada enam aspek keterampilan berpikir kritis, yaitu interpretasi, analisis, evaluasi, inferensi, penjelasan, dan regulasi diri (Facione, 2015). Interpretasi adalah memahami makna dan makna dari situasi, data atau peristiwa yang berbeda, kemampuan ini membantu untuk mengklasifikasikan, mendefinisikan makna, dan memperjelas makna. Analisis adalah penentuan maksud dan kesimpulan yang sebenarnya dalam hubungan antara pernyataan, konsep, deskripsi, atau bentuk pernyataan yang dimaksudkan untuk mengungkapkan keyakinan, keputusan, pengalaman, alasan, informasi, keyakinan, atau pendapat. Evaluasi adalah kemampuan untuk menilai keandalan suatu pernyataan atau representasi lain dengan mengevaluasi atau menggambarkan persepsi, pengalaman, situasi, keputusan, keyakinan seseorang, dan dengan menilai kekuatan logika hubungan yang diprediksi atau hubungan aktual yang disimpulkan antara pernyataan, deskripsi, pernyataan, atau bentuk representasi lainnya. Inferensi adalah kemampuan untuk mengidentifikasi dan memilih faktor-faktor yang diperlukan untuk sampai pada kesimpulan yang masuk akal atau membentuk hipotesis dengan memperhatikan informasi yang relevan dan meminimalkan konsekuensi yang timbul dari data, pernyataan, prinsip, bukti, penilaian, keyakinan, pendapat, konsep, deskripsi. dan bentuk representasi lainnya. Intepretasi adalah tindakan mengungkapkan sudut pandang seseorang atau membenarkan suatu sudut pandang berdasarkan bukti, kriteria, atau konteks. Keterampilan ini memungkinkan persuasi dan penggunaan kriteria mendalam untuk mendukung keputusan. Regulasi diri, yaitu menyatakan hasil proses berpikir, kemampuan menalar berdasarkan bukti, konsep, metodologi, kriteria tertentu dan keseimbangan yang wajar, serta kemampuan menginterpretasikan 
nalar dalam bentuk argumentasi. Berpikir kritis merupakan salah satu keterampilan pembelajaran dan inovasi abad 21, yang berperan penting dalam mempersiapkan mahasiswa menghadapi masalah sosial, ilmiah, dan praktis di masa depan (El Soufi \& See, 2019; Gojkov et al., 2015; Snyder \& Snyder, 2008).

Pengembangan keterampilan berpikir kritis mahasiswa selama proses pembelajaran dapat dilakukan dengan strategi sebagai berikut: 1) penyusunan materi yang baik; 2) membahas materi kontroversial; 3) mengangkat isu-isu yang menyebabkan konflik kognitif; 3) meminta mahasiswa untuk menemukan sudut pandang yang berbeda terhadap suatu masalah; 5) menugaskan mahasiswa untuk menulis artikel untuk publikasi di jurnal; 6) menganalisis artikel atau media lain untuk ide-ide baru; 7) mengusulkan masalah untuk menemukan solusi yang berbeda; 8) menyarankan bacaan alternatif bagi mahasiswa untuk diperdebatkan atau didiskusikan; dan 9) mengundang mereka yang memiliki pandangan kontroversial (Kordaki \& Daradoumis, 2009; Kwan \& Wong, 2015).

Keterampilan berpikir kritis juga dapat ditingkatkan melalui beberapa upaya, salah satunya adalah belajar dari analisis masalah. Karakteristik pembelajaran yang dapat memperkuat berpikir kritis mahasiswa adalah pembelajaran menggunakan interaksi mahasiswa, memberikan mahasiswa cukup waktu untuk berpikir tentang pertanyaan dan masalah, dan membangun berdasarkan semua keterampilan dan pengalaman yang telah diperoleh mahasiwa (Firdaus et al., 2015). Berpikir kritis dapat diperkuat dengan kegiatan yang didasarkan pada konsep berpikir kritis. Konsep berpikir kritis meliputi identifikasi masalah, inkuiri rasional, analisis konseptual, penalaran logis, penalaran cerdas, dan pembentukan kesimpulan dapat disajikan oleh dosen dalam pembelajaran sehari-hari (Adeyemi, 2012; Aizikovitsh-Udi \& Cheng, 2015).

\section{Model Discovery Learning}

Model Discovery Learning merupakan model yang mengembangkan pembelajaran aktif mahasiswa dengan penemuan diri, partisipasi, dan hasil yang diperoleh akan bertahan lama dalam ingatan dan mahasiswa tidak mudah dilupakan, berkat model penemuan mahasiswa juga dapat belajar berpikir analitis dan mencoba memecahkan masalahnya sendiri (Lestari, 2018; Ulfa \& Oktaviana, 2021; Wedekaningsih et al., 2019). Model Discovery Learning merupakan teori belajar yang diartikan sebagai proses belajar yang terjadi ketika mahasiswa tidak disajikan dalam bentuk final, tetapi mahasiswa diminta untuk mengorganisasikan dirinya (Winangun, 2020). Pembelajaran penemuan berakar pada teori Jerome S. Brunner bahwa peran utama seorang dosen adalah membantu dan mendorong mahasiswa untuk mengeksplorasi konsep dan ide yang berbeda dan untuk mengembangkan aspek eksplorasi, pengetahuan dan pemahaman, pengetahuan dan eksperimen (Kyriazis et al., 2009). Penjelasan lebih lanjut dari model pembelajaran penemuan membantu mahasiswa memahami konsep, makna, dan hubungan, melalui proses intuitif, hingga akhirnya mencapai suatu kesimpulan. Hal ini terjadi ketika mahasiswa terlibat, terutama dalam menggunakan proses mentalnya untuk menemukan konsep dan prinsip tertentu. Model Discovery Learning meliputi mengamati, mengklasifikasi, mengukur, memprediksi, mengidentifikasi, dan menyimpulkan. Proses ini dikenal sebagai proses kognitif sedangkan penemuan itu sendiri adalah proses mental asimilasi konsep dan prinsip ke dalam pikiran (Putra \& Amalia, 2020).

Sintak penerapan model Discovery Learning adalah stimulation, problem statement, data collection, data processing, verification, dan generalization (Kemendikbud, 2013). Adapun keenam langkah penerapan model Discovery Learning yang diterapkan adalah sebagai berikut: 
1402 Potensi Pemberdayaan Keterampilan Berpikir Kritis Mahasiswa Calon Guru Sekolah Dasar Melalui Model Discovery Learning - Anggit Grahito Wicaksono

DOI: https://doi.org/10.31004/basicedu.v6i1.2229

Tabel 1. Sintaks Penerapan Model Discovery Learning

\begin{tabular}{|c|c|}
\hline Sintaks & Kegiatan Pembelajaran \\
\hline Stimulation & $\begin{array}{l}\text { Pada tahap ini, mahasiswa dihadapkan pada berbagai masalah dan didorong } \\
\text { untuk membaca dan mengeksplorasi dari berbagai sumber dengan topik } \\
\text { tertentu sebagai titik awal untuk mempersiapkan pemecahan masalah. }\end{array}$ \\
\hline Problem Statement & $\begin{array}{l}\text { Setelah stimulation selesai, langkah kedua adalah dosen memberikan } \\
\text { kesempatan kepada mahasiswa untuk mengidentifikasi berbagai masalah } \\
\text { terkait dengan yang disajikan pada tahap pertama dan merumuskan hipotesis } \\
\text { masalah untuk mengeksplorasi masalah yang sebenarnya. }\end{array}$ \\
\hline Data Collection & $\begin{array}{l}\text { Langkah ini merupakan eksplorasi dari berbagai sumber referensi yang } \\
\text { terlibat dalam mengidentifikasi masalah yang telah diidentifikasi mahasiswa. } \\
\text { Langkah ini juga dilakukan untuk menanggapi posisi dan hipotesis yang } \\
\text { dibuat oleh mahasiswa. Penting untuk mengumpulkan berbagai sumber } \\
\text { dukungan untuk menjawab dan menguji hipotesis. }\end{array}$ \\
\hline Data Processing & $\begin{array}{l}\text { Berbagai informasi yang diperoleh mahasiswa direduksi, diolah, diklasifikasi, } \\
\text { ditabulasi bahkan dihitung dengan menggunakan rumus-rumus tertentu untuk } \\
\text { diinterpretasikan dengan tingkat keyakinan tertentu. }\end{array}$ \\
\hline Verification & $\begin{array}{l}\text { Langkah ini diambil untuk secara hati-hati meninjau dan memvalidasi data } \\
\text { yang diperoleh, dibangun, dan disajikan. Pengetahuan baru tentang alternatif } \\
\text { pemecahan masalah diperlukan pada tahap ini. }\end{array}$ \\
\hline Generalization & $\begin{array}{l}\text { Penarikan kesimpulan merupakan proses terakhir dalam langkah ini. } \\
\text { Kesimpulan digunakan sebagai aturan umum untuk masalah serupa. }\end{array}$ \\
\hline
\end{tabular}

Kelebihan dari model Discovery Learning adalah pengetahuan yang diperoleh melalui metode ini sangat pribadi dan kuat karena meningkatkan pemahaman, memori dan transfer (Artawan et al., 2020; Winangun et al., 2021). Konsolidasi pemahaman, memori (dalam memori jangka panjang), dan transmisi yang dimaksudkan dalam kaitannya dengan materi yang dipelajari. Keterampilan ini memudahkan mahasiswa untuk menguasai materi yang dipelajarinya. Daya ingat mahasiswa terhadap materi pembelajaran meningkat, hal ini sejalan dengan peningkatan kemampuan berpikir kritisnya. Salah satu ukuran keberhasilan model pembelajaran Discovery Learning adalah internalisasi peristiwa dalam "sistem penyimpanan" yang adaptif terhadap lingkungan (Bruner, 2009; Nurmala \& Priantari, 2017). Hal ini mengarah pada penerapan model pembelajaran penemuan di luar kelas atau lingkungan. Mahasiswa mengamati secara langsung di lingkungan untuk memperoleh data pengamatan secara langsung. Observasi yang dilakukan secara langsung di lingkungan harus dapat menggabungkan pengetahuan mahasiswa berdasarkan apa yang diperoleh di kelas atau dari sumber lain selain yang sebenarnya terjadi di lingkungan (Juniarso, 2020).

\section{Potensi Discovery Learning dalam Memberdayakan Keterampilan Berpikir Kritis}

Model pembelajaran penemuan memiliki potensi besar dalam mengembangkan kemampuan berpikir kritis mahasiswa. Tahapan model pembelajaran penemuan digabungkan untuk menciptakan pembelajaran mandiri dan melatih kemampuan berpikir mahasiswa (Putra \& Amalia, 2020). Model pembelajaran penemuan memberikan pengalaman mahasiswa dalam mencari pengetahuan sendiri dan menggunakan pendekatan saintifik (Klahr \& Nigam, 2004). Alasan lain untuk mengadopsi model pembelajaran penemuan adalah memungkinkan mahasiswa untuk belajar dengan baik dan membuat kemajuan lebih cepat dalam pola pikir mereka (Kwan \& Wong, 2015), dengan memberikan kesempatan kepada mahasiswa untuk berpikir dan berdiskusi secara ilmiah dan menggunakan keterampilan berpikir kritis (Bianchini \& Colburn, 2000; Hwang \& Chang, 2011). Dari perbedaan pendapat di atas dapat dikatakan bahwa model Discovery Learning berpusat pada mahasiswa, agar mahasiswa berperan sebagai peserta aktif, kondisi ini menuntut mahasiswa untuk lebih fokus pada pembelajaran langsung tetapi umumnya kesempatan untuk meningkatkan keterampilan berpikir kritis. dengan mengumpulkan informasi tentang prosedur otentikasi dan investigasi. 
1403 Potensi Pemberdayaan Keterampilan Berpikir Kritis Mahasiswa Calon Guru Sekolah Dasar Melalui Model Discovery Learning - Anggit Grahito Wicaksono

DOI: https://doi.org/10.31004/basicedu.v6i1.2229

Tabel 2. Keterkaitan Potensi Pemberdayaan Keterampilan Berpikir Kritis Melalui Model Discovery Learning

\begin{tabular}{|c|c|c|c|}
\hline \multirow{2}{*}{ No } & \multicolumn{2}{|c|}{ Keterampilan Berpikir Kritis Menurut Facione } & \multirow{2}{*}{$\begin{array}{c}\text { Sintaks Discovery } \\
\text { Learning }\end{array}$} \\
\hline & Aspek & Indikator & \\
\hline \multirow{3}{*}{1} & \multirow{3}{*}{ Interpretasi } & Klasifikasi & \multirow{2}{*}{ Stimulation } \\
\hline & & Membuat kode (Coding) & \\
\hline & & Mendefinisikan istilah & Problem Statement \\
\hline \multirow{2}{*}{2} & \multirow{2}{*}{ Analisis } & Mengumpulkan ide & \multirow{2}{*}{ Data Collection } \\
\hline & & Berargumen & \\
\hline \multirow{2}{*}{3} & \multirow{2}{*}{ Evaluasi } & Mengeklaim & \multirow{2}{*}{ Data Processing } \\
\hline & & Mempertimbangkan argumen & \\
\hline \multirow{2}{*}{4} & \multirow{2}{*}{ Kesimpulan } & Memilih sumber & \multirow{2}{*}{ Verification } \\
\hline & & Membuat kesimpulan & \\
\hline \multirow{2}{*}{5} & \multirow{2}{*}{ Penjelasan } & Menafsirkan hasil & \multirow{3}{*}{ Generalization } \\
\hline & & Menilai argumen & \\
\hline 6 & Pengaturan Diri & Koreksi diri & \\
\hline
\end{tabular}

Berdasarkan Tabel 2. menjelaskan bahwa sintaks model Discovery Learning memiliki keterkaitan serta berpotensi dapat memberdayakan keterampilan berpikir kritis mahasiswa. Sintaks pembelajaran yang pertama adalah stimulation. Stimulation memberikan kondisi agar interaksi belajar berkembang dan membantu mahasiswa dalam mengeksplorasi materi (Sinambela, 2017). Keterampilan berpikir kritis mahasiswa yang dapat dikembangkan selama fase stimulation adalah keterampilan yang dibutuhkan untuk mengklasifikasikan masalah dan membuat kode terhadap masalah (coding). Stimulation mirip dengan aktivasi, berfungsi sebagai dasar kognitif untuk aktivasi otak dan mengarahkannya ke literatur penelitian (Utomo, 2016). Tahap kedua dari pembelajaran adalah pernyataan masalah. Mahasiswa diberi kesempatan untuk mengidentifikasi sebanyak mungkin fakta dari masalah terkait topik, setelah itu sebuah fakta dipilih dan dirumuskan menjadi hipotesis (jawaban sementara atas pertanyaan masalah) (Sinambela, 2017). Keterampilan berpikir kritis yang dapat ditingkatkan dalam sintaks ini adalah keterampilan mahasiswa dalam mengidentifikasi istilah-istilah yang muncul dari masalah kehidupan nyata. Sintaks pembelajaran yang ketiga adalah pengumpulan data. Pengumpulan data digunakan untuk menjawab pertanyaan atau untuk membuktikan kebenaran suatu hipotesis. Akibatnya, mahasiswa memiliki kesempatan untuk mengumpulkan informasi yang relevan, membaca sumber belajar, mengamati topik, menginterogasi sumber, membuat karangan sendiri dan kegiatan terkait lainnya (Sinambela, 2017). Kegiatan pengumpulan data dilakukan untuk meningkatkan indikator kemampuan berpikir kritis mahasiswa khususnya pengumpulan ide dan penalaran. Sintaks pembelajaran keempat adalah pengolahan data. Pengolahan data adalah kegiatan mengolah data dan informasi yang diperoleh melalui wawancara, observasi dan sejenisnya. kemudian ditafsirkan (Syah, 2013). Kegiatan pengolahan data ini dapat meningkatkan sejumlah indikator kemampuan berpikir kritis mahasiswa, yaitu kemampuan mereka membuat pernyataan terhadap argumen dan mempertimbangkan argumen. Sintaks pembelajaran kelima menyangkut verifikasi. Pada tahap ini dilakukan pengujian yang cermat untuk menunjukkan bahwa hipotesis yang telah ditetapkan benar untuk beberapa fenomena yang diketahui, terkait dengan hasil pengolahan data (Syah, 2013). Kegiatan ini merupakan bagian dari upaya untuk meningkatkan kemampuan berpikir kritis mahasiswa, terutama keterampilan yang diperlukan untuk memilih sumber dan menarik kesimpulan. Sintaks keenam adalah generalisasi, tahap generalisasi adalah proses penarikan kesimpulan yang dapat dijadikan prinsip umum dan berlaku untuk semua fakta atau masalah yang sama, dengan memperhatikan kesimpulan hasil verifikasi (Syah, 2013). Kegiatan ini merupakan bagian dari upaya untuk meningkatkan kemampuan berpikir kritis mahasiswa terutama dalam hal indikator keterampilan menginterpretasikan hasil, mengevaluasi argumentasi, dan mengoreksi hasil. 
1404 Potensi Pemberdayaan Keterampilan Berpikir Kritis Mahasiswa Calon Guru Sekolah Dasar Melalui Model Discovery Learning - Anggit Grahito Wicaksono

DOI: https://doi.org/10.31004/basicedu.v6i1.2229

\section{KESIMPULAN}

Model pembelajaran Discovery Learning memiliki potensi yang amat besar untuk memberdayakan keterampilan berpikir kritis mahasiswa. Sintaks yang ada pada model pembelajaran Discovery Learning yang meliputi Stimulation, Problem Statement, Data Collection, Data Processing, Verification, dan Generalization mampu melatihkan dan memberdayakan keterampilan berpikir kritis pada mahasiswa menjadi lebih terarah. Keterampilan berpikir kritis dapat diberdayakan di setiap tahapan sintaks Discovery Learning.

\section{UCAPAN TERIMA KASIH}

Artikel publikasi ini merupakan hasil dari Penelitian yang didanai oleh Lembaga Penelitian dan Pengabdian kepada Masyarakat (LPPM) Universitas Slamet Riyadi. Terimakasih kepada LPPM UNISRI yang telah mendanai program ini sehingga dapat terlaksana dengan lancar.

\section{DAFTAR PUSTAKA}

Adeyemi, S. B. (2012). Developing Critical Thinking Skills In Students: A Mandate For Higher Education In Nigeria. European Journal Of Educational Research, 1(2), 155-161. Https://Doi.Org/10.12973/EuJer.1.2.155

Aizikovitsh-Udi, E., \& Cheng, D. (2015). Developing Critical Thinking Skills From Dispositions To Abilities: Mathematics Education From Early Childhood To High School. Creative Education, 06(04), 455-462. Https://Doi.Org/10.4236/Ce.2015.64045

Anugraheni, I. (2019). Analisis Kemampuan Berpikir Kritis Mahasiswa Dalam Menyelesaikan Permasalahan Bilangan Bulat Berbasis Media Realistik. Scholaria: Jurnal Pendidikan Dan Kebudayaan, 9(3), 276283.

Arifani, N. H., As'ari, A. R., \& Abadyo, A. (2017). Proses Berpikir Siswa Kelas Viii Dalam Menyelesaikan Soal Matematika Timss Materi Besar Sudut Dalam Bentuk Geometris. Jurnal Pendidikan: Teori, Penelitian, Dan Pengembangan, 2(7), 946-954.

Artawan, P. G. O., Kusmariyatni, N., \& Sudana, D. N. (2020). Pengaruh Model Pembelajaran Discovery Learning Terhadap Hasil Belajar Ipa. Jurnal Ilmiah Pendidikan Profesi Guru, 3(3), 452. Https://Doi.Org/10.23887/Jippg.V3i3.29456

Batubara, I. H. (2020). Pengaruh Model Pembelajaran Guided Discovery Learning Terhadap Hasil Belajar Pengembangan Silabus Pembelajaran Matematika Pada Masa Pandemic Covid 19. Jurnal Penelitian, Pendidikan Dan Pengajaran: Jppp, 1(2), 13. Https://Doi.Org/10.30596/Jppp.V1i2.4948

Bianchini, J. A., \& Colburn, A. (2000). Teaching The Nature Of Science Through Inquiry To Prospective Elementary Teachers: A Tale Of Two Researchers. Journal Of Research In Science Teaching: The Official Journal Of The National Association For Research In Science Teaching, 37(2), 177-209.

Bruner, J. S. (2009). The Process Of Education. Harvard University Press.

Danandjaja, J. (2014). Metode Penelitian Kepustakaan. Antropologi Indonesia, 52. Https://Doi.Org/10.7454/Ai.V0i52.3318

Ebiendele Ebosele Peter. (2012). Critical Thinking: Essence For Teaching Mathematics And Mathematics Problem Solving Skills. African Journal Of Mathematics And Computer Science Research, 5(3). Https://Doi.Org/10.5897/Ajmcsr11.161

Efendi, D. (2019). Pengembangan Bahan Ajar Matematika Dengan Model Discovery Learning Untuk Mengembangkan Keterampilan Berpikir Kritis. Eksponen, 9(1), 42-54. Https://Doi.Org/10.47637/Eksponen.V9i1.132 
1405 Potensi Pemberdayaan Keterampilan Berpikir Kritis Mahasiswa Calon Guru Sekolah Dasar Melalui Model Discovery Learning - Anggit Grahito Wicaksono

DOI: https://doi.org/10.31004/basicedu.v6i1.2229

El Soufi, N., \& See, B. H. (2019). Does Explicit Teaching Of Critical Thinking Improve Critical Thinking Skills Of English Language Learners In Higher Education? A Critical Review Of Causal Evidence. Studies In Educational Evaluation, 60(December 2018), 140-162. Https://Doi.Org/10.1016/J.Stueduc.2018.12.006

Ennis, R. H. (1996). Critical Thinking Dispositions: Their Nature And Assessability. Informal Logic, 18(2), 165-182. Https://Doi.Org/10.22329/Il.V18i2.2378

Facione, P. A. (2015). Critical Thinking: What It Is And Why It Counts. Insight Assessment.

Facione, P. A., \& Facione, N. C. (2013). Critical Thinking For Life. Inquiry: Critical Thinking Across The Disciplines, 28(1), 5-25. Https://Doi.Org/10.5840/Inquiryct20132812

Firdaus, F., Kailani, I., Bakar, M. N. Bin, \& Bakry, B. (2015). Developing Critical Thinking Skills Of Students In Mathematics Learning. Journal Of Education And Learning (Edulearn), 9(3), 226-236. Https://Doi.Org/10.11591/Edulearn.V9i3.1830

Firmansyah, A., \& Rizal, R. (2019). Potret Keterampilan Berpikir Kritis Dan Motivasi Berprestasi Mahasiswa Pgsd Universitas Tadulako. Jurnal Inspirasi Pendidikan, 9(2), 103-109. Https://Doi.Org/10.21067/Jip.V9i2.3323

Galbreath, J. (1999). Preparing The 21st Century Worker: The Link Between Computer-Based Technology And Future Skill Sets. Educational Technology, 39(6), 14-22. Http://Www.Jstor.Org/Stable/44428565

Gojkov, G., Stojanović, A., \& Rajić, A. G. (2015). Critical Thinking Of Students - Indicator Of Quality In Higher Education. Procedia - Social And Behavioral Sciences, 191(2012), 591-596. Https://Doi.Org/10.1016/J.Sbspro.2015.04.501

Hwang, G.-J., \& Chang, H.-F. (2011). A Formative Assessment-Based Mobile Learning Approach To Improving The Learning Attitudes And Achievements Of Students. Computers \& Education, 56(4), 1023-1031.

Juniarso, T. (2020). Model Discovery Learning Terhadap Kemampuan Berpikir Kreatif Mahasiswa. Else (Elementary School Education Journal): Jurnal Pendidikan Dan Pembelajaran Sekolah Dasar, 4(1), 36-43.

Kemendikbud, M. P. I. K. (2013). Model Pembelajaran Penemuan (Discovery Learning). Jakarta: Badan Pengembangan Sumber Daya Manusia Pendidikan Dan Kebudayaan Dan Penjaminan Mutu Pendidikan, Kementerian Pendidikan Dan Kebudayaan.

Klahr, D., \& Nigam, M. (2004). The Equivalence Of Learning Paths In Early Science Instruction: Effects Of Direct Instruction And Discovery Learning. Psychological Science, 15(10), 661-667. Https://Doi.Org/10.1111/J.0956-7976.2004.00737.X

Kordaki, M., \& Daradoumis, T. (2009). Thinking Dimensions As A Foundation Of Learning Design. Https://Doi.Org/10.1109/Icalt.2009.13

Kwan, Y. W., \& Wong, A. F. L. (2015). Effects Of The Constructivist Learning Environment On Students' Critical Thinking Ability: Cognitive And Motivational Variables As Mediators. International Journal Of Educational Research, 70, 68-79.

Kyriazis, A., Psycharis, S., \& Korres, K. (2009). Discovery Learning And The Computational Experiment In Higher Mathematics And Science Education: A Combined Approach. International Journal Of Emerging Technologies In Learning (Ijet), 4(4), 25-34. Https://Www.Learntechlib.Org/P/45149

Lai, E. (2011). Critical Thinking: A Literature Review. Pearson's Res Rep, 6, 40-41.

Lestari, K. P. (2018). Pengaruh Model Discovery Learning Berbantuan Media Audio Visual Dalam Setting Lesson Study Terhadap Hasil Belajar Ipa Mahasiswa Pgsd Undiksha Upp Denpasar Tahun 2017. Jurnal Ilmiah Sekolah Dasar, 2(1), 40. Https://Doi.Org/10.23887/Jisd.V2i1.13895

Mulyono, Y. (2018). Critical Thinking Skills Of Physics Education Students Through Ctl-Based Fundamental 
1406 Potensi Pemberdayaan Keterampilan Berpikir Kritis Mahasiswa Calon Guru Sekolah Dasar Melalui Model Discovery Learning - Anggit Grahito Wicaksono

DOI: https://doi.org/10.31004/basicedu.v6i1.2229

Biology. Science, Engineering, Education, And Development Studies (Seeds): Conference Series, 2(1). Https://Doi.Org/10.20961/Seeds.V2i1.24646

Munawwarah, M., Laili, N., \& Tohir, M. (2020). Keterampilan Berpikir Kritis Mahasiswa Dalam Memecahkan Masalah Matematika Berdasarkan Keterampilan Abad 21. Alifmatika: Jurnal Pendidikan Dan Pembelajaran Matematika, 2(1), 37-58. Https://Doi.Org/10.35316/Alifmatika.2020.V2i1.37-58

Nurmala, R. S., \& Priantari, I. (2017). Meningkatkan Keterampilan Komunikasi Dan Hasil Belajar Kognitif Melalui Penerapan Discovery Learning Improving Communication Skills And Cognitive Study Result Through Discovery Learning. Bioma: Jurnal Biologi Dan Pembelajaran Biologi, 2(1).

Ozdem-Yilmaz, Y., \& Bilican, K. (2020). Discovery Learning-Jerome Bruner (Pp. 177-190). Https://Doi.Org/10.1007/978-3-030-43620-9_13

Putra, E. D., \& Amalia, R. (2020). Upaya Meningkatkan Kemampuan Berpikir Kritis Mahasiswa Melalui Pembelajaran Discovery Learning Berbasis Assessment Learning. Journal Of Education And Learning Mathematics Research (Jelmar), 1(1), 57-64. Https://Doi.Org/10.37303/Jelmar.V1i1.17

Sakti, I., Defianti, A., \& Nirwana, N. (2020). Implementasi Modul Ipa Berbasis Etnosains Masyarakat Bengkulu Materi Pengukuran Melalui Discovery Learning Untuk Meningkatkan Kemampuan Berpikir Kritis Mahasiswa. Jurnal Kumparan Fisika, 3(3), 232-238. Https://Doi.Org/10.33369/Jkf.3.3.232-238

Sari, M., \& Asmendri. (2018). Penelitian Kepustakaan (Library Research) Dalam Penelitian Pendidikan Ipa. Penelitian Kepustakaan (Library Research) Dalam Penelitian Pendidikan Ipa, 2(1), 15 Https://Ejournal.Uinib.Ac.Id/Jurnal/Index.Php/Naturalscience/Article/View/1555/1159

Sinambela, P. N. J. M. (2017). Kurikulum 2013 Dan Implementasinya Dalam Pembelajaran. Generasi Kampus, 6(2).

Snyder, L. G., \& Snyder, M. J. (2008). Teaching Critical Thinking And Problem Solving Skills. The Journal Of Research In Business Education, 50(2), 90-99.

Sucipto, S. (2017). Pengembangan Ketrampilan Berpikir Tingkat Tinggi Dengan Menggunakan Strategi Metakognitif Model Pembelajaran Problem Based Learning. Jurnal Pendidikan (Teori Dan Praktik), 2(1), 77. Https://Doi.Org/10.26740/Jp.V2n1.P77-85

Susanti, W., Sukrianto, D., \& Ramadhani, D. (2020). Pengaruh Model Discovery Learning Dalam Kemampuan Berpikir Kritis Dan Cognitif Mahasiswa Program Studi Sistem Informasi. Invotek: Jurnal Inovasi Vokasional Dan Teknologi, 20(3), 53-62. Https://Doi.Org/10.24036/Invotek.V20i3.742

Syah, M. (2013). Psikologi Belajar.

Takaya, K. (2008). Jerome Bruner's Theory Of Education: From Early Bruner To Later Bruner. Interchange, 39(1), 1-19. Https://Doi.Org/10.1007/S10780-008-9039-2

Ulfa, M., \& Oktaviana, E. (2021). Peningkatan Kemampuan Berliterasi Melalui Model Discovery Learning Berbantuan Media Pohon Literasi. Jurnal Basicedu, 5(6), 5204-5212.

Utomo, D. H. (2016). Pengembangan Bahan Ajar Meteorologi-Klimatologi Berdasarkan Brain Based Learning. Disertasi. Program Studi Pendidikan Geografi. Disertasi Dan Tesis Program Pascasarjana $U m$.

Walker, P., \& Finney, N. (2006). Skill Development And Critical Thinking In Higher Education. Teaching In Higher Education, 4(4), 531-547. Https://Doi.Org/10.1080/1356251990040409

Wedekaningsih, A., Koeswati, H. D., \& Giarti, S. (2019). Penerapan Model Discovery Learning Untuk Meningkatkan Keterampilan Berpikir Kritis Dan Hasil Belajar Matematika. Jurnal Basicedu, 3(1), 2126.

Wicaksono, A. G. (2020). Systematic Review Pengaruh Pendekatan Saintifik Terhadap Peningkatan Keterampilan Berpikir Kritis Siswa. Profesi Pendidikan Dasar, 7(1), 65-76. Https://Doi.Org/10.23917/Ppd.V7i1.10822 
1407 Potensi Pemberdayaan Keterampilan Berpikir Kritis Mahasiswa Calon Guru Sekolah Dasar Melalui Model Discovery Learning - Anggit Grahito Wicaksono

DOI: https://doi.org/10.31004/basicedu.v6i1.2229

Winangun, I. M. A. (2020). Penerapan Model Discovery Learning Berbasis Digital Untuk Meningkatkan Motivasi Dan Hasil Belajar Mahasiswa Pada Mata Kuliah Media Pembelajaran Sd. E- Jurnal Mitra Pendidikan, 4(5), 256-268. Https://Doi.Org/10.52160/E-Jmp.V4i5.722

Winangun, I. M. A., Wiguna, I. K. W., \& Tristaningrat, M. A. N. (2021). Model Guided Discovery Learning Berorientasi Pembelajaran Abad 21 Bermuatan Tri Kaya Parisudha. Mimbar Ilmu, 26(3), 355. Https://Doi.Org/10.23887/Mi.V26i3.39893

Wiyoko, T. (2019). Analisis Profil Kemampuan Berpikir Kritis Mahasiswa Pgsd Dengan Graded Response Models Pada Pembelajaran Ipa. Ijis Edu : Indonesian Journal Of Integrated Science Education, 1(1), 25. Https://Doi.Org/10.29300/Ijisedu.V1i1.1402 